\title{
PROMOSI MEDIA FILM BERBAHASA BENGKULU BERPENGARUH TERHADAP PENGETAHUAN DAN MOTIVASI WANITA DALAM DETEKSI DINI KANKER SERVIKS MELALUI IVA TES
}

\author{
PROMOTION OF BENGKULU LANGUAGE MOVIE MEDIA \\ INFLUENCING TOWARDS KNOWLEDGE AND MOTIVATION OF \\ WOMEN IN EARLY DETECTION OF CANCER SERVICES \\ THROUGH IVA TEST
}

\author{
Lusi Andriani,Sri Yanniarti, Mariati, Elvi Destariyani* \\ *Poltekkes Kemenkes Bengkulu, Bengkulu Province Indonesia \\ Korespondensi: lusianto80@gmail.com
}

\begin{abstract}
The incidence of Cervical cancer about 16/ 100,000 women, 70\% of deaths occur in poor and developing countries. It is estimated that approximately 528,000 new cases of cervical cancer and caused 266,000 people to die.The purpose of this study to determine the impact of local language movies on knowledge and motivation Women in the implementation of early detection of cervical cancer by the IVA test. This study uses a quantitative method with a design quasiexperimental pre and post-test with control group design, data were collected using a questionnaire. Samples were 60 women in Kampung Melayu district area consists of 30 people as the intervention group and 30 in the comparison group. The data analysis used univariate, the bivariate test of T-dependent and T-test Independent, multivariate use MANCOVA.

Results showed knowledge before and after intervention increased from 10.73 into 12.80 with pvalue(0.000) and Motivation scores increase of 56.57 into 60.40 with p-value (0.002). There are significant differences between the intervention group and the comparison group with $p$ value(0.002) for the knowledge and $p(0.000)$ for motivation. There was a significant effect of the variable Independent Movie towards Knowledge and Motivation women with pValue 0.00 , covariate variable does not affect the knowledge and motivation with p-Value greater than $\alpha=0.05$. Need to campaign on an ongoing basis to be able to motivate women in carrying out the examination IVA and the media that is used needs to be varied so that women interested and more easily understand the message.
\end{abstract}

Keywords : Knowledge, Motivation, Cervical Cancer, VIA, Movie Media

\section{PENDAHULUAN}

Kanker merupakan penyebab kematian utama nomor dua di dunia. Saat ini kanker serviks diperkirakan menjadi penyebab kematian 7,5 juta orang di dunia. Insiden kanker serviks sebesar $\quad 16 / 100.000$ perempuan, $70 \%$ kematian akibat kanker ini terjadi di Negara miskin dan berkembang. Di Indonesia pada tahun 2014 kematian akibat kanker mencapai 92.200 orang, 10,3\% di antaranya disebabkan oleh kanker serviks. Menurut data dari Yayasan Kanker 
Indonesia tahun 2015, diperkirakan setiap hari muncul 40-45 kasus baru, 20-25 orang meninggal. Setiap jam diperkirakan 1 orang perempuan meninggal dunia karena kanker serviks.

Deteksi dini dapat menurunkan angka penyakit kanker "stadium lanjut" sehingga angka kesembuhan penyakit kanker menjadi meningkat. Skrining merupakan upaya deteksi dini untuk mengidentifikasi penyakit atau kelainan yang secara klinis belum jelas dengan menggunakan tes, pemeriksaan atau prosedur tertentu (Kemenkes RI, 2015).

Upaya deteksi dini dapat digunakan secara cepat untuk membedakan orangorang yang kelihatannya sehat tetapi sesungguhnya menderita suatu kelainan. Metode penapisan di Indonesia yang lebih mampu dilaksanakan, murah dan efektif adalah Inspeksi Visual dengan Asam Asetat (IVA) yang ditemukan oleh Hinselmen di tahun 1925, IVA dapat membedakan antara leher rahim yang normal dan tidak normal dengan cara yang murah, mudah tersedia dan cepat (Emilia, 2010).

Estimasi jumlah kasus kanker serviks Provinsi Bengkulu tahun 2013 menurut Data Riset Kesehatan Dasar (2013), sebanyak 705 orang. Berdasarkan Profil Kesehatan Provinsi Bengkulu didapatkan data dari 3 Kabupaten dengan jumlah positif IVA tertinggi. Wilayah Bengkulu Tengah 71 orang $(17,36 \%)$ dari jumlah WUS
14.900, Rejang Lebong 22 orang $(5,08 \%)$ dari 38.299 WUS, Muko-muko 16 orang $(3,21 \%)$ dari 38.299 WUS (Dinkes Provinsi, 2015).

Jumlah perempuan di Provinsi Bengkulu tahun 2016 usia 30-50 tahun adalah 267.779 orang, sedangkan yang melakukan pemeriksaan deteksi dini kanker mulut rahim dan payudara berjumlah 2.529 orang dengan menggunakan metode IVA dengan hasil IVA positif berjumlah 127 orang.

Hasil penelitian Aswathy dkk (2012) di India menunjukkan bahwa (74,2 \%) mengetahui bahwa kanker serviks dapat diketahui secara dini melalui skrining tes, sebagian besar responden $(89,2 \%)$ tidak mengetahui faktor risiko kanker serviks, hanya $(6,9 \%)$ yang pernah melakukan skrining. Faktor yang mempengaruhi WUS tidak melakukan skrining adalah pengetahuan yang kurang $(51,4 \%)$, tidak mempunyai uang, waktu $(15,1 \%)$ dan faktor psikososial (10,2\%). Sedangkan faktor yang mempengaruhi WUS melakukan tes adalah usia $>35$, mempunyai pengetahuan tentang skrining kanker serviks dengan nilai $(P<0.05$ (Aswathy, Amin Quereshi and Leelamoni, 2012)

Salah satu upaya untuk menciptakan perilaku masyarakat yang kondusif untuk kesehatan adalah melalui pendidikan kesehatan yaitu kegiatan untuk 
meningkatkan pengetahuan, sikap dan perilaku masyarakat. Pendidikan kesehatan yang telah dilakukan pada program tes IVA di Kota Bengkulu pada umumnya adalah metode ceramah tanya jawab dengan media lembar balik. Rekomendasi dari hasil penelitian di 12 Puskesmas Kabupaten Karawang pada tahun 2009 yang bertujuan untuk mengevaluasi program tes IVA dari tahun 2007 sampai dengan 2008 memberikan rekomendasi agar media pendidikan kesehatan lebih ditingkatkan untuk meningkatkan cakupan program tes IVA (Ghazali, 2009).

Daerah Kecamatan Kampung Melayu merupakan salah satu kecamatan yang ada di pinggiran kota Bengkulu dan berbatasan dengan Kabupaten Seluma. Hasil survey awal yang dilakukan peneliti tentang deteksi dini kanker servik dengan IVA test, 7 dari 10 ibu yang di wawancara mengatakan tidak mengetahui tentang pemeriksaan tersebut dan apa fungsinya serta belum pernah diperiksa atau memeriksakan diri.

Tujuan penelitian yang dilakukan adalah diketahui pengaruh media film berbahasa Bengkulu terhadap pengetahuan dan motivasi WUS dalam pelaksanaan deteksi dini kanker serviks dengan IVA tes.

\section{METODE}

Penelitian ini menggunakan metode kuantitatif dengan rancangan quasi eksperimen pre and post test with control group design, Sampel adalah 60 orang WUS di wilayah kecamatan Kampung Melayu terdiri dari 30 orang WUS sebagai kelompok intervensi dan 30 WUS sebagai kelompok pembanding. WUS yang terpilih menjadi responden adalah WUS yang memenuhi kriteria inklusi sebagai berikut : 1) Belum pernah melakukan pemeriksaan IVA tes atau Pap Smear, 2) Berusia 15-50 tahun, 3) Sudah menikah atau sudah pernah melakukan hubungan seksual, 4) Berdomisili menetap di lokasi penelitian, 5) Bersedia menjadi responden sedangkan kriteria inklusi adalah WUS yang mengalami pengangkatan rahim (histerektomi) dan WUS yang sudah terdiagnosa kanker servik. Analisis data yang digunakan univariat, bivariat uji $\mathrm{T}$ dependent dan Uji $\mathrm{T}$ Independent, multivariat menggunakan MANCOVA. Penelitian telah mendapatkan persetujuan etik dari Komisi Etik Poltekkes Kemenkes Bengkulu.

\section{HASIL DAN PEMBAHASAN}

\section{Karakteristik WUS di Wilayah Kecamatan Kampung Melayu Kota Bengkulu}

Tabel 1 menunjukkan sebagian besar $(63.3 \%)$ berpendidikan rendah, sebagian besar $(78.3 \%)$ WUS memiliki paritas Multipara/Grandemultipara, lebih dari 
sebagian $(56,7 \%)$ ibu berusia antara $<20 />35$ tahun dan sebagian besar $(96.7 \%)$ ibu tidak bekerja

Tabel 1 Karakteristik WUS di Wilayah Kecamatan Kampung Melayu Kota Bengkulu

\begin{tabular}{llll}
\hline No & Variabel & $\mathrm{n}=60$ & $\mathbf{1 0 0 \%}$ \\
\hline 1 & Pendidikan & & \\
& Rendah: SD-SLTP & 38 & 63.3 \\
& Tinggi: SLTA/PT & 22 & 36.7 \\
& & & \\
\hline 2 & Paritas & & \\
& Nullipara/Primipara & 13 & 21.7 \\
& $\begin{array}{l}\text { Multipara/Grandemulti } \\
\text { para }\end{array}$ & 47 & 78.3 \\
\hline 3 & Usia & & \\
& 20-35 Tahun & 26 & 43.3 \\
& <20/>35 Tahun & 34 & 56.7 \\
& & & \\
\hline 4 & Pekerjaan & & \\
& Bekerja & 2 & 3.3 \\
& Tidak Bekerja & 58 & 96.7 \\
& & \\
\hline
\end{tabular}

Dalam penelitian ini walaupun sebagian besar ibu-ibu berpendidikan rendah namun mereka bisa menerima penkes yang diberikan dan mau melaksanakan anjuran atau pesan yang disampaikan dalam penkes tersebut. Hal ini sesuai dengan penelitian Mulyati (2012) dan Denny (2000) yang menyatakan bahwa media yang digunakan dalam menyampaikan pesan mempengaruhi keberhasilan pesan yang disampaikan (Mulyati, Suwarsa and Arya, 2013)(Denny Lynette, 2000)
Pekerjaan seseorang dapat mempengaruhi penghasilan dan pendapatan. Semakin tinggi ekonomi seseorang, semakin mudah pula upaya menerima informasi baru sehingga akhirnya dapat mempengaruhi hasil dari pendidikan kesehatan tentang kanker serviks dan tes IVA (Selmouni et al., 2015). Pekerjaan responden pada penelitian ini adalah berada pada status hampir seluruhnya tidak bekerja, dalam arti lain kebutuhan keluarga semua dipenuhi oleh suami, sehingga kemungkinan hal ini juga mempengaruhi perilaku ibu-ibu dalam melakukan pemeriksaan. Pada penelitian ini walaupun sebagian besar responden tidak bekerja akan tetapi hasil penelitian menunjukan terdapat peningkatan pada pengetahuan, motivasi dan keikutsertaan ibu pada tes IVA. Hal ini dimungkinkan adanya faktor lain yang mempengaruhinya misalnya faktor dukungan sosial dan mereka telah mempunyai asuransi kesehatan, sedangkan pemeriksaan deteksi dini dengan IVA tes ini dicover oleh asuransi kesehatan, sehingga sangat menungkinkan ibu-ibu dapat melakukan pemeriksaan. (Jeronimo et al., 2014)(Karisma, 2011). Selain karakteristik pekerjaan, terlihat juga bahwa sebagian besar responden memiliki paritas multipara dan grandemultipara. Responden yang telah melahirkan memiliki resiko untuk memiliki lesi prakanker, menurut hasil penelitian ibu 
dengan paritas $\geq 3$ lebih beresiko memiliki lesi prakanker sehingga responden pada usia tersebut akan merasa lebih penting untuk
Motivasi dengan selisih rata-rata 0.34 .

Tabel 2 Perbedaan skor Pengetahuan dan Motivasi sebelum dan setelah pemberian intervensi Media Film

\begin{tabular}{|c|c|c|c|c|c|c|c|}
\hline \multirow{2}{*}{\multicolumn{2}{|c|}{$\begin{array}{l}\text { melakukan tes IVA } \\
\text { (Mulyati, Suwarsa and }\end{array}$}} & \multirow{2}{*}{$\begin{array}{l}\text { Intervensi } \\
\text { Media Film }\end{array}$} & \multicolumn{5}{|c|}{ Skor Pengetahuan dan Motivasi } \\
\hline & & & Mean & $\triangle$ Mean & $\mathbf{N}$ & SD & P value \\
\hline \multicolumn{2}{|c|}{ Arya, 2013) } & $\begin{array}{l}\text { Pengetahuan } \\
\text { Sebelum }\end{array}$ & 10.73 & 2.07 & 30 & 1.552 & 0.000 \\
\hline Perbedaan & Skor & Pengetahuan & 12.80 & & & 1.690 & \\
\hline Pengetahuan & dan & $\begin{array}{l}\text { Setelah } \\
\text { Motivasi }\end{array}$ & 56.57 & 3.83 & 30 & 3.202 & 0.002 \\
\hline Motivasi & Pada & Sebelum & & & & & \\
\hline Kelompok & Intervensi & $\begin{array}{l}\text { Motivasi } \\
\text { Setelah }\end{array}$ & 60.40 & & & 6.629 & \\
\hline
\end{tabular}

\section{dan Pembanding}

Tabel 2, 3 dan 4 menunjukkan rerata skor pengetahuan sebelum diberikan intervensi Media Film adalah 10.73 dan setelah

diberikan

intervensi

\begin{tabular}{llllll}
\hline Intervensi & Media & \multicolumn{5}{l}{ Skor Pengetahuan dan Motivasi } \\
\cline { 2 - 6 } Konvensional & Mean & $\Delta$ Mean & N & SD & P value \\
\hline Pengetahuan Sebelum & 10.70 & 0.33 & 30 & 2.423 & 0.202
\end{tabular}

terjadi

peningkatan

Pengetahuan Setelah

Motivasi Sebelum

11.03

52.03

0.34

30

2.385

7.513

0.294

skor

pengetahuan

dengan rerata 12.80 dan selisih rata-rata 2.7.

Demikian Juga dengan Skor Motivasi terjadi peningkatan dengan selisih rata-rata 3.83. Sedangkan pada kelompok media
Tabel 3 Perbedaan skor Pengetahuan dan Motivasi sebelum dan setelah pemberian intervensi Media Konvensional

\begin{tabular}{|c|c|c|c|c|c|c|c|}
\hline konvensional & & & \multicolumn{5}{|c|}{ Pengetahuan dan Motivasi } \\
\hline teriadi & Variabel & & Mean & $\triangle$ Mean & $\mathbf{N}$ & SD & P value \\
\hline peningkatan & $\begin{array}{l}\text { Pengetahuan } \\
\text { Intervensi }\end{array}$ & Kelompok & 12.80 & 1.37 & 30 & 1.690 & 0.002 \\
\hline yang bermakna & $\begin{array}{l}\text { Pengetahuan } \\
\text { Pembanding }\end{array}$ & Kelompok & 11.43 & & & 2.385 & \\
\hline dengan selisih & Motivasi & Kelompok & 60.40 & 8.03 & 30 & 6.626 & 0.000 \\
\hline $\begin{array}{ll}\text { rata-rata } & 0.33 \\
\text { dan } & \text { Skor }\end{array}$ & $\begin{array}{l}\text { Intervensi } \\
\text { Motivasi } \\
\text { Pembanding }\end{array}$ & Kelompok & 52.37 & & & 7.815 & \\
\hline
\end{tabular}


Hasil penelitian ini sejalan dengan penelitian Karisma (2011) dan Mulyati (2012) dimana pendidikan kesehatan dapat meningkatkan praktek/perilaku ibu dalam meningkatkan pengetahuan dalam bidang kesehatan. Notoatmodjo (2003) menyatakan setelah dilakukan pendidikan kesehatan pengetahuan seseorang dapat meningkat dan akan di sertai peningkatan sikap dan perilaku. Berdasarkan Green (1991) bahwa pendidikan kesehatan dapat mengubah perilaku dan membantu pencapaian tujuan yang di inginkan.

Pada hasil penelitian didapatkan bahwa pendidikan kesehatan yang menggunakan metode konvensional yaitu hanya ceramah saja tidak memberikan perbedaan yang signifikan antara pengetahuan dan motivasi sebelumnya. Hal ini berarti ceramah dan film lebih efektif digunakan untuk meningkatkan pengetahuan dan motivasi pada responden dari pada hanya melalui ceramah saja. Hal ini disebabkan karena pada umur 35-50 waktu yang efektif digunakan adalah untuk mendengarkan dan melihat dari pada membaca, didukung oleh pendidikan ibu yang sebagian besar rendah sehingga dengan melihat film yang ditayangkan lebih menarik dengan film yang juga menggunakan bahasa daerah sehingga lebih mudah dimengerti.

Penelitian ini sejalan dengan penelitian Sulastri, dkk (2015) yang menyatakan bahwa metode penkes ceramah+audiovisual lebih efektif dibandingkan dengan penkes dengan metode ceramah+buku saku. Demikian juga dengan penelitian Sri Mulyati, dkk (2014) yang menyatakan terdapat pengaruh positif penkes melalui film terhadap sikap ibu dalam deteksi dini melalui IVA tes. Ni Nyoman Hartati, dkk (2016) juga mendapatkan hasil bahwa motivasi ibu dalam melakukan deteksi dini kanker serviks terbanyak pada motivasi sedang berjumlah 29 orang $(52,7 \%)$.

Dalam penelitian ini semua ibu belum melakukan pemeriksaan IVA, dari hasil diskusi pada saat penelitian diketahui bahwa sebagian responden merasa takut untuk melakukan deteksi dini kanker serviks karena khawatir kalau periksa justru akan mengetahui penyakitnya, dan membuat responden merasa cemas.

Keberhasilan pendidikan kesehatan dapat dipengaruhi oleh tingkat pendidikan karena pendidikan dapat mempengaruhi cara pandang seseorang terhadap informasi baru yang diterimanya. Semakin tinggi tingkat 
pendidikannya, semakin mudah seseorang menerima informasi yang didapatkannya (Notoatmodjo, 2007). Hal ini sesuai dengan hasil penelitian ini yang menunjukan bahwa banyak responden berpendidikan rendah tapi $60 \%$ responden ikut serta pada tes IVA. Hal tersebut dapat diakibatkan oleh penyerapan informasi dengan pendidikan kesehatan melalui film merupakan metode yang efektif bagi masyarakat baik yang berpendidikan rendah maupun tinggi.(Nurseto, 2011)

Pada penelitian ini, seluruh responden penelitian adalah wanita usia subur yang memenuhi syarat untuk melakukan tes IVA akan tetapi mereka belum pernah melakukan tes IVA. Banyak faktor yang dapat mempengaruhi perilaku tersebut, diantaranya adalah motivasi ibu. (Proma Paul et all, 2007) Pada penelitian ini telah dilakukan pemberian pendidikan kesehatan pada responden. Upaya tersebut sesuai dengan teori yang menyebutkan bahwa salah satu upaya yang dapat dilakukan untuk mempengaruhi pengetahuan dan motivasi ibu pada perilaku kesehatan adalah melalui pendidikan kesehatan (Notoatmodjo, 2007).

Hasil analisis menunjukan bahwa pemberian pendidikan kesehatan melalui film berpengaruh terhadap sikap ibu pada tes IVA. Hasil uji statistik menunjukan terdapat perbedaan bermakna antara sebelum dan setelah pemberian pendidikan kesehatan melalui film $(\mathrm{P}<0,05)$. Hasil penelitian ini sesuai dengan penelitian Lestari Handayani yang menunjukan bahwa terdapat pengaruh yang signifikan dari pendidikan kesehatan melalui media audiovisual terhadap perubahan sikap seseorang (nilai $\mathrm{p}<0,05$ ). Pada penelitian tersebut menyatakan bahwa media audiovisual merupakan media yang efektif yang dapat meningkatkan sikap seseorang (Handayani, 2010).

Media audiovisual merupakan media yang efektif karena media audiovisual dapat memberikan informasi secara jelas melalui gambar dan suara. Hal ini sejalan dengan teori yang menyebutkan bahwa film sebagai suatu media audiovisual memungkinkan sinyal audio dapat dikombinasikan dengan gambar bergerak. Film dapat mempermudah penerimaan informasi. tingkat retensi (daya serap dan daya ingat) peserta didik terhadap materi pembelajaran dapat meningkat secara signifikan jika proses perolehan informasi melalui indera pendengaran dan penglihatan (visualisasi). Menurut 
penelitian, indera paling banyak menyalurkan pengetahuan ke dalam otak adalah mata. Kurang lebih $75 \%$ sampai $87 \%$ dari pengetahuan manusia diperoleh melalui mata. Kurang lebih $13 \%$ sampai $25 \%$ dari pengetahuan diperoleh melalui indera lain.

Selain film dapat mempermudah penyerapan informasi, film sebagai media pembelajaran juga dapat berfungsi afektif yaitu dapat menggugah perasaan, emosi dan tingkat penerimaan atau penolakan responden terhadap sesuatu. Pada penelitian ini film berisi kejadian yang dapat menggugah perasaan penonton misalnya dengan ditampilkannya tokoh yang memiliki penyakit kanker leher rahim, dan tokoh yang memiliki hasil tes IVA positif sehingga membuat responden sedih dan merasa takut jika mengalami hal yang serupa dengan kejadian pada film yang ditontonnya. Hal ini sesuai dengan teori yang menyebutkan bahwa isi pesan pada film dapat berpengaruh secara signifikan terhadap perasaan, emosi, tingkat penerimaan atau penolakan terhadap informasi yang diberikan (Nurseto,
2011).

Film pada penelitian ini memperlihatkan latar belakang yang sama dengan latar belakang responden misalnya lingkungan tempat tinggal, pekerjaan, paritas, dan alasan masyarakat di lokasi penelitian yang tidak mau ikutserta pada tes IVA. Lingkungan tempat tinggal responden merupakan lingkungan dengan geografis perkebunan sawit dan dekat laut dengan sebagian besar pekerjaan penduduknya adalah petani dan nelayan. Rata-rata paritas penduduk adalah 2-3 anak sesuai dengan angka dengan angka Total Fertility Rate. Selain itu latar belakang film ini juga disesuaikan dengan hasil wawancara pada saat study pendahuluan penelitian yaitu salah satu faktor yang mengakibatkan ibu tidak menjalani tes IVA diantaranya adalah adanya pengetahuan dan motivasi yang kurang baik seperti malu untuk memeriksakan diri, merasa tidak perlu memeriksakan diri dan merasa tes IVA tidak penting.

\section{Pengaruh Intervensi Media Film terhadap Pengetahuan dan Motivasi WUS dalam Deteksi Dini Kanker Serviks}

\section{Tabel 5 Pengaruh Media Film Terhadap Pengetahuan dan Motivasi}

\begin{tabular}{llcrrrrrrr}
\hline $\begin{array}{l}\text { Independent } \\
\text { Variabel }\end{array}$ & $\begin{array}{l}\text { Dependent } \\
\text { Variabel }\end{array}$ & $\begin{array}{c}\text { Type III Sum of } \\
\text { Squares }\end{array}$ & df & Mean Square & F & Sig. & $\begin{array}{c}\text { Noncent. } \\
\text { Parameter }\end{array}$ & $\begin{array}{c}\text { Observed } \\
\text { Power }^{\mathrm{b}}\end{array}$ \\
\hline Intervensi & Pengetahuan & $8606.697^{\mathrm{a}}$ & 6 & 1434.449 & 371.863 & .000 & 2231.178 & 1.000 \\
\cline { 2 - 11 } Media Film & Motivasi & $191834.794^{\mathrm{c}}$ & 6 & 31972.466 & 590.825 & .000 & 3544.952 & 1.000 \\
\hline
\end{tabular}


Dari hasil uji Mancova didapatkan ada pengaruh yang signifikan dari variabel Independen Media Film terhadap Pengetahuan dan Motivasi WUS dalam pemeriksaan IVA, hal ini dilihat dari nilai signifikansi $p$ Value 0.000 lebih kecil dari nilai $\alpha=0.05$ pada tingkat asumsi $95 \%$. Sedangkan variabel kovariat (usia, paritas, pendidikan dan pekerjaan) tidak mempengaruhi pengetahuan dan motivasi, hal ini ditunjukkan dari nilai $p$ Value yang lebih besar dari $\alpha=0.05$ terhadap

Meskipun dari hasil akhir analisis multivariat kovarian disimpulkan tidak terdapat pengaruh atau hubungan yang cukup signifikan secara statistik antara variabel kovariat dengan variabel dependen, namun dilihat dari ibu-ibu yang melakukan pemeriksaan IVA tidak hanya dari kelompok yang dilakukan intervensi Film tetapi ada juga yang dari kelompok dengan media Konvensional yaitu hanya diberikan metode ceramah saja. Hal ini menunjukkan bahwa motivasi ibu-ibu untuk melakukan pemeriksaan telah ada dan memang diperlukan suatu dorongan dari luar sehingga mereka benar-benar melaksanakan perilaku pemeriksaan. Ibu-ibu tersebut kemungkinan telah menyadari dengan kondisi karakteristik mereka dilihat dari usia menikah muda, telah mempunyai anak lebih dari dua ataupun dari riwayat keputihan yang pernah dialami dan melihat di media elektronik bahwa ancaman kanker serviks dapat terjadi pada wanita manapun asalkan telah berhubungan seksual.(Vedantham et al., 2010) (African Population and Health Research Center, International Agency for Research on Cancer, 2003)

\section{SIMPULAN}

Dari hasil penelitian didapatkan sebagian besar responden berpendidikan rendah, sebagian besar WUS memiliki paritas Multipara/Grandemultipara, lebih dari sebagian berusia antara $<20 />35$ tahun dan sebagian besar tidak bekerja. Ada perbedaan nilai rata-rata pengetahuan dan motivasi sebelum dan setelah intervensi media Film, sedangkan pada kelompok pembanding tidak ada perbedaan. Ada perbedaan nilai rata-rata pengetahuan dan motivasi pada kelompok intervensi dan kelompok pembanding. Ada pengaruh intervensi media film terhadap pengetahuan dan motivasi WUS setelah mengontrol variabel usia, paritas, pendidikan dan pekerjaan.

\section{DAFTAR RUJUKAN}

African Population and Health Research Center, International Agency for Research on Cancer, W. H. O. (2003) 'Prevention of cervical cancer through 
screening using visual inspection with acetic acid ( VIA ) and treatment with cryotherapy', Outlook, II(1), p. 33. doi: 10.1155/2010/268925.

Aswathy, S., Amin Quereshi, M. and Leelamoni, K. (2012) 'Cervical Cancer Screening: Current Knowledge and Practice Among Women in A Rural Population of Kerala India', Indian Journal Medical Research, 136(2), pp. 205-210.

Denny Lynette (2000) An Evaluation of Alternative Strategies for the Prevention of Cervical Cancer in Low-Resource Settings. University of Cape Town and Groote Schuur Hospital University.

Dinkes Provinsi (2015) 'Profil Kesehatan Provinsi Bengkulu'.Dinas Kesehatan Propinsi Bengkulu

Emilia, O. (2010) Bebas Ancaman Kanker Serviks. Yogyakarta: Media Pressindo.

Globacan (2012) 'Estimated Cancer Incidence Mortality, Prevalence and Disability - adjusted Life Years (DALYs) Worldwide in 2008', IARC Cancer Base, 11.

Jeronimo, J., Bansil, P., Lim, J., Peck, R., Paul, P., Amador, J. J., Mirembe, F., Byamugisha, J., Poli, U. R., Satyanarayana, L. and Asthana, S. (2014) 'A Multicountry Evaluation of careHPV Testing, Visual Inspection With Acetic Acid, and Papanicolaou Testing for the Detection of Cervical Cancer', International Journal of Gynecological Cancer, 24(3), pp. 576-585. doi: 10.1097/IGC.0000000000000084.

Karisma, S. L. (2011) Pengaruh promosi kesehatan terhadap pengetahuan tentang kanker serviks dan partisipasi wanita dalam deteksi dini kanker serviks UNIVERSITAS SEBELAS MARET.

Kemenkes RI (2015) 'Kesehatan Dalam Kerangka Sustainable Development Goals (SDGs)', (97), p. 85.

Kementerian Kesehatan (2015) Profil Kesehatan Indonesia 2014, Kementerian Kesehatan Republik Indonesia. doi:
10.1037/0022-3514.51.6.1173.

Mulyati, S., Suwarsa, O. and Arya, I. F. D. (2013) 'Pengaruh Media Film Terhadap Sikap Ibu Pada Deteksi Dini Kanker Serviks', Jurnal Kesehatan Masyarakat, 8(2), pp. 113-120. doi: ISSN 1858-1196.

Nurseto, T. (2011) 'Membuat Media Pembelajaran yang Menarik - Tejo Nurseto', Ekonomi \& Pendidikan, 8, pp. 19-35.

Proma Paul et all, (2007) 'Screen-andTreatApproachto CervicalCancerPrevention Using Visual InspectionWithAcetic AcidandCryotherapy: Experiences, Perceptions, andBeliefsFromDemonstration Projects in Peru, Uganda,andVietnam', October, pp. 1467-1470. doi: 10.1634/theoncologist.12-12-1467.

Selmouni, F., Zidouh, A., Alvarez-Plaza, C. and El Rhazi, K. (2015) 'Perception and satisfaction of cervical cancer screening by Visual Inspection with Acetic acid (VIA) at Meknes-Tafilalet Region, Morocco: A population-based cross-sectional study', BMC Women's Health. BMC Women's Health, 15(1), pp. 1-6. doi: 10.1186/s12905-015-0268-0.

Sulistiowati, E. and Sirait, A. M. (2014) 'Pengetahuan Tentang Faktor Risiko, Perilaku Dan Deteksi Dini Kanker Serviks Dengan Inspeksi Visual Asam Asetat (Iva) Pada Wanita Di Kecamatan Bogor Tengah, Kota Bogor', Buletin Penelitian Kesehatan, 42(3), pp. 193-202.

Vedantham, H., Silver, M. I., Kalpana, B., Rekha, C., Karuna, B. P., Vidyadhari, K., Mrudula, S., Ronnett, B. M., Vijayaraghavan, K., Ramakrishna, G., Sowjanya, P., Laxmi, S., Shah, K. V. and Gravitt, P. E. (2010) 'Determinants of VIA (visual inspection of the cervix after acetic acid application) positivity in cervical cancer screening of women in a peri-urban area in Andhra Pradesh, India', Cancer Epidemiology Biomarkers and Prevention, 19(5), pp. 1373-1380. doi: 10.1158/10559965.EPI-09-1282. 